\author{
Dr. sc. Josip Vučković
}

\title{
KONTROLA USTAVNOSTI I ZAKONITOSTI NAREDBE
}

\author{
UDK: $342.56(497.5)$ \\ $340.137(497.5)$ \\ DOI: $10.31141 /$ rrpfs.2020.57.138.987 \\ Izvorni znanstveni rad \\ Primljeno: 15. lipnja 2020.
}

\begin{abstract}
Zakonska ovlaštenja za donošenje naredbi u osnovi omogućuju pravodobno normiranje različitih izvanrednih situacija, u okviru kojih naredbodavac, najčešće ministar, privremeno naređuje neko postupanje ili propuštanje koje inače nije obvezatno ili se zabranjuje neko postupanje koje je inače zakonom dopušteno. Dosadašnja praksa pokazuje, međutim, da takva ovlaštenja, temeljem kojih se gospodarskim subjektima redovito ograničava kakvo na temelju zakona stečeno pravo, odnosno nameće kakva dodatna obveza ili trpljenje, često formuliraju općenito, bez jasno utvrđenih granica naredbodavne ovlasti. U ovom se radu problematizira nedorečenost novog sustavnog uređenja naredbe, koje ostavlja otvorenim pitanje nadležnosti za kontrolu ustavnosti i zakonitosti tih općeobvezujućih podzakonskih akata. Naredba, naime, u ovom trenutku ne može biti predmet objektivnog upravnog spora, a upitna je i nadležnost Ustavnog suda, imajući u vidu da Zakon o sustavu državne uprave naredbu više izrijekom ne definira kao provedbeni propis. Slijedom toga, u glavnom dijelu rada analiziraju se temeljna materijalna obilježja i pravna priroda naredbe, razmatra se pitanje nužnog stupnja određenosti i preciznosti ovlašćujuće norme i uloga načela razmjernosti u nužnom limitiranju normativne autonomije zakonodavca i naredbodavca te se, zaključno, nastoji odgovoriti na pitanje treba li (i može li) naredba biti predmet ustavnosudske kontrole ustavnosti i zakonitosti.
\end{abstract}

Ključne riječi: naredba, ograničavanje prava i sloboda, vladavina prava, pravna sigurnost, načelo razmjernosti

\section{UVOD}

Kad je riječ o normativnim ovlaštenjima javnopravnih tijela koja djeluju u okvirima naše državne uprave, ${ }^{1} \mathrm{u}$ hrvatskom pozitivnom pravu tradicionalno se javljaju zakonska ovlaštenja za donošenje provedbenih propisa čiji nositelji mogu biti pojedini članovi Vlade (ministri) te čelnici drugih tijela državne uprave bez kabinetskog statusa (državne upravne organizacije), a u posljednje vrijeme i pojedina kolegijalna tijela pravnih osoba s javnim ovlastima („neovisna regulatorna tijela“) u kontekstu provedbe pravno obvezujućih akata Europske unije u području regulacije

1 Pod time razumijevamo različita javnopravna tijela koja, neovisno o njihovu službenom nazivu i/ili pravnom obliku, primarno obavljaju izvorne ili povjerene poslove državne uprave. 
i nadzora zakonom određenih tržišta javnih usluga. ${ }^{2} \mathrm{U}$ svim tim slučajevima radi se o ovlaštenjima koja nastaju u okviru primjene određenog oblika normativne delegacije, ${ }^{3}$ gdje pojedini javnopravni subjekti, koji nemaju izvornih normativnih ovlasti, normativnu ovlast stječu na temelju općeg ili posebnog zakonskog ovlaštenja kojim se nužno određuju opseg, sadržaj, a nerijetko i svrha te ovlasti. ${ }^{4}$ Propisi koji se donose na temelju takvih normativnih ovlaštenja s teorijskog aspekta smatraju se podzakonskim općenormativnim aktima, ${ }^{5}$ odnosno zakonima u materijalnom smislu. ${ }^{6}$

Sam izraz provedbeni propis predstavlja opću zakonsku klasifikaciju podzakonskih propisa za provedbu zakona koja je donedavno, do stupanja na snagu novoga Zakona o sustavu državne uprave (dalje: ZSDU/19), ${ }^{7}$ obuhvaćala pravilnike, naredbe i naputke, okvirno definirane prema normativnom sadržaju i svrsi njihova donošenja. ${ }^{8}$ Takva klasifikacija bila je nužna jer Ustav Republike Hrvatske šuti o vrstama, svrsi i mogućim donositeljima provedbenih propisa koji, unatoč tome što su dekonstitucionalizirani još 1990 . godine, ${ }^{9}$ čine značajan dio našeg pozitivnog prava. U nedostatku izričite ustavne odredbe, pitanje zakonske norme koja nekom podzakonskom općenormativnom aktu daje karakter ,propisa“ postaje od iznimne

2 Vidi Smerdel, Branko, Ustavno uređenje europske Hrvatske, Narodne novine, Zagreb, 2013., str. $432-433$

3 U tom smislu i Banić, Slavica, ,Režim općih akata nakon donošenja zakona o upravnim sporovima (2010)“, Zbornik radova Pravnog fakulteta u Splitu, 50(3), 2013., str. 573. gdje autorica ističe da „Pravo na donošenje normativnih akata uprava crpi iz ovlaštenja predstavničkog tijela koje određuje njegov karakter i obujam (...), riječ je o delegiranom pravu koje je ograničeno karakterom i obujmom danog ovlaštenja“.

4 Normativna delegacija u najširem smislu predstavlja pravnu radnju između dva javnopravna subjekta kojom izvorni nositelj određene normativne ovlasti (delegant) stvara novu, opsegom užu, normativnu ovlast na strani drugog subjekta (delegatar). Delegacija se vrši delegirajućim aktom (zakonom) kojim se, uz delegatara, utvrđuju sadržaj i opseg delegirane ovlasti, a nerijetko i svrha delegacije, ako nije već određena u višoj (ustavnoj) normi, vidi Barić, Sanja, Zakonodavna delegacija i parlamentarizam u suvremenim europskim državama, Organizator, Zagreb, 2009., str. 52. Navodimo samo ustaljenu definiciju normativne delegacije u širem smislu, koja obuhvaća srodne, no zasebne javnopravne institute zakonodavne delegacije i normativne delegacije neovisnim upravnim tijelima, čije je razmatranje izvan nužno ograničenog fokusa ovog rada.

5 Za širu definiciju vidi Omejec, Jasna i Banić, Slavica, „Diferencijacija propisa i općih akata u budućoj praksi Ustavnog suda i Upravnog suda u povodu Zakona o upravnim sporovima“, Zbornik radova Pravnog fakulteta u Splitu, 49(2), 2012., str. 318-319, Ivančević, Velimir, Institucije upravnog prava knjiga I, Pravni fakultet Sveučilišta u Zagrebu, Zagreb, 1983., str. 85, Borković, Ivo, Upravno pravo, Narodne novine, Zagreb, 2002., str. 101.

6 O teoriji materijalnog pojma zakona opširnije u Ivančević, op. cit., str. 31-34, vidi i Barić, op. cit., str. 23-24. Za razmatranja klasičnih autora vidi Jellinek, Georg, Gesetz und Verordnung, Mohr, Freiburg, 1887., str. 226-261, Laband, Paul, Das Staatsrecht des Deutschen Reiches, Mohr, Freiburg, 1895., str. 540-546, Krbek, Ivo, Upravno pravo, I. knjiga, Uvodna i osnovna pitanja, Tisak i naklada Jugoslovenske štampe, Zagreb, 1929., str. 10-15.

7 Zakon o sustavu državne uprave (NN, br. 66/19).

8 Govorimo o općoj klasifikaciji koju su, od 1993. na ovamo, sadržavali svi organski zakoni kojima je bio uređen sustav državne uprave, o dosadašnjem uređenju novinama u tom pogledu opširnije infra.

9 Stupanjem na snagu Ustava Republike Hrvatske (NN, br. 56/90). Prema dotadašnjem uređenju, preciznije odredbi čl. 406. Ustava Socijalističke Republike Hrvatske (NN, br. 8/74), ,republički sekretari i funkcionari koji rukovode drugim republičkim organima uprave“ mogli su ,donositi pravilnike, naredbe i uputstva za izvršavanje zakona i propisa Izvršnog vijeća ako su za to ovlašteni zakonom odnosno propisom Izvršnog vijeća“. 
važnosti jer se, osim na pravne učinke toga akta, neposredno reflektira i na obvezu njegove publikacije u Narodnim novinama, mogućnost povratnog djelovanja te, ${ }^{10}$ što je $s$ aspekta vladavine prava možda i najznačajnije, na ustavnosudsku nadležnost za ocjenu suglasnosti takvog akta s Ustavom i zakonom i moguće pravne učinke ustavnosudske odluke o njegovoj neustavnosti ili nezakonitosti, utvrđene Ustavom i razrađene u Glavi IV. Ustavnog zakona o Ustavnom sudu Republike Hrvatske (dalje: UZUS). ${ }^{11}$ Pogrešno je, međutim, barem kada je riječ o jurisdikciji Ustavnog suda, povući znak jednakosti između podzakonskog općenormativnog akta, koji je prvenstveno teorijska konstrukcija, ${ }^{12}$ i „,drugog propisa“ iz članaka 90., 126. i 127. Ustava, odnosno Glave IV. UZUS-a. Naime, ako nema ni zakonske odredbe koja neki općenormativni akt izričito kvalificira propisom, mjerodavna je definicija „drugog propisa“ koji je Ustavni sud utvrdio Rješenjem br. U-II-5157/2005, ${ }^{13}$ gdje se pod tim pojmom razumijeva: „eksterni općenormativni i pravno obvezujući akt koji je donijelo tijelo državne vlasti radi uređenja pojedinih pitanja, izvršenja i/ili provedbe zakona, odnosno provedbe drugog propisa više pravne snage, koji uređuje odnose na općenit način i koji djeluje prema svima koji se nađu u pravnoj situaciji da se na njih dotični akt ima primijeniti“, dok se „drugim propisom“ ne smatraju: „eksterni i interni opći akti koje donose tijela jedinica lokalne i područne (regionalne) samouprave, druge pravne osobe s javnim ovlastima i pravne osobe koje obavljaju javnu službu u smislu članka 3. stavka 2. ZUS-a“. ${ }^{14}$ Dakle, u nedostatku izričite ustavne i zakonske norme, možemo govoriti o dva temeljna mjerila za određenje nekog podzakonskog općenormativnog akta ,drugim propisom“. To su: materijalna obilježja samog akta (apstraktnost i generalnost) i norma o nadležnosti, odnosno ovlaštenom donositelju toga akta koja mora biti tijelo državne uprave, odnosno

10 Čl. 90. st. 1. Ustava uređuje se obveza objava zakona i „drugih propisa državnih tijela“ u Narodnim novinama, a st. 4. istog čl. isključuje se njihovo povratno djelovanje. Redovito vakacijsko razdoblje je pak u stavku 3. istog članka utvrđeno samo za zakone, čime je njegovo određenje za ,druge propise“ prepušteno zakonodavcu, vidi i točku 16. Odluke br. U-I-3845/2006 od 23. I. 2013. (NN, br. 12/13). Izraz „drugi propis“ uveden je još Božićnim ustavom te nije mijenjan ni definiran pri kasnijim promjenama Ustava, vidi Omejec i Banić, op. cit., str. 311.

11 Odredbama čl. 125. i 126. Ustava utvrđena je nadležnost Ustavnog suda za kontrolu suglasnosti „drugih propisa“ s Ustavom i zakonom i pravni učinci ustavnosudskih odluka u odnosu na „druge propise“. Prema čl. 55. UZUS-a odluka o neustavnosti „drugog propisa“ može imati invalidacijski (ex nunc) učinak, ali može rezultirati i nulifikacijom, odnosno poništavanjem (ex tunc) sporne norme za koju Ustavni sud utvrdi, imajući u vidu težinu povrede Ustava ili zakona i interes pravne sigurnosti, da se njome vrijeđaju ljudska prava i temeljne slobode ili se njome pojedinci, skupine ili udruge neosnovano stavljaju u povoljniji ili nepovoljniji položaj. Opširnije u Smerdel, op. cit., str. 339-341.

12 „Sam izraz podzakonski općenormativni akt prvenstveno je teoretska konstrukcija. Njome se želi izraziti dvije temeljne misli: 1. da se radi o apstraktnom i generalnom pravilu ponašanja - o općoj normativnosti, $\mathrm{i} 2$. da takvo pravilo stoji ispod zakona. To njegovo svojstvo proizlazi iz principa ustavnosti odnosno zakonitosti i ima kao neizbježivu posljedicu da ga se u odnosu prema zakonu mora smatrati propisom nižeg reda“, prema Ivančević, op. cit., str. 85.

13 Rješenje br. U-II-5157/2005 od 5.3.2012. (NN, br. 41/12). Definicija je „iznuđena“ uvođenjem objektivnog upravnog spora u hrvatski pravni sustav 2012. godine, odnosno, u svrhu razgraničenja „drugih propisa“ za čiju je ocjenu nadležan Ustavni sud, od „općih akata“ čiju zakonitost ocjenjuje Visoki upravni sud, imajući u vidu da se u oba slučaja radi o objektivnim sporovima s ciljem zaštite objektivnog pravnog poretka, a kako bi se spriječio pozitivni ili negativni sukob nadležnosti, opširnije u Omejec i Banić, op. cit., str. 317-319.

14 Ibid. 
drugo državno tijelo. Međutim, ni ta mjerila nisu apsolutna s obzirom na to da je Ustavni sud istim Rješenjem utvrdio da može provesti kontrolu ustavnosti i zakonitosti i „općeg akta“ tijela državne vlasti koji ima samo jedno materijalno obilježje „drugog propisa“ (apstraktnost ili generalnost), ,ako ocijeni da je to nužno radi zaštite ljudskih prava i temeljnih sloboda zajamčenih Ustavom i drugih najviših vrednota ustavnog poretka Republike Hrvatske utvrđenih u članku 3. Ustava“ “. ${ }^{15} \mathrm{U}$ tom slučaju se osporavani opći akt u okviru ustavnosudskog postupka ipak tretira kao „drugi propis“, što znači da se ispituje je li donesen od ovlaštenog tijela/osobe, je li donositelj imao ovlaštenje za njegovo donošenje (pravna osnova donošenja) te je li osporavani akt po svom sadržaju u granicama koje je odredio zakon. ${ }^{16}$

Ovdje pak govorimo o specifičnoj (pod)vrsti normativnih ovlaštenja - za donošenje naredbi - (za potrebe ovoga rada označavamo ih kao naredbodavna ovlaštenja) koja, prema ZSDU/19, ministrima i drugim čelnicima tijela državne uprave omogućuju da „naređuju i zabranjuju određeno postupanje“, odnosno da „određuju druge privremene interventne mjere radi trenutačne zaštite pravnog poretka te zaštite života, sigurnosti, zdravlja stanovništva ili imovne veće vrijednosti u određenom području“ . ${ }^{17}$ Iako su interventne mjere, osobito u kontekstu recentnih događaja vezanih uz pandemiju uzrokovanu virusom SARS - CoV-2, definitivno bliže fokusu šire javnosti, činjenica jest da su naredbodavna ovlaštenja u našoj pravnoj literaturi rijetko bivala predmetom neke opsežnije analize. ${ }^{18}$ To, međutim, ne treba čuditi s obzirom na njihovo dosadašnje uređenje u zakonima koji su uređivali sustav državne uprave, ZSDU/11, ${ }^{19}$ odnosno ZSDU/93, ${ }^{20}$ gdje je naredba bila tek šturo definirana kao provedbeni propis kojim se „naređuje ili zabranjuje određeno postupanje“, dok su odredbe o ovlaštenjima za donošenje provedbenih propisa bile sistematizirane među ,poslove državne uprave“, iz čega je, ako bismo se držali gramatike tih zakona, pogrešno proizlazilo da se radi o obavljanju „poslova“, koji su, zajedno s rješavanjem u upravnim stvarima i vođenjem raznih očevidnika (i izdavanjem potvrda iz istih), inherentni državnoj upravi. Širi značaj naredbe dolazi do izražaja tek promotrimo li ovlaštenja sadržana u nizu posebnih zakona,

15 Ibid. Vidi i Krapac, Davor, Postupak pred Ustavnim sudom Republike Hrvatske, ustrojstvo i proceduralni elementi ustavnog nadzora, Narodne novine, Zagreb, 2014., str.. 152-153. Ustavni sud je ovu iznimku promijenio već u Odluci br.: U-II-5748/2013 od 20. XII. 2013. (NN, br. 159/13), kojom je ukinuo Odluku Vlade Republike Hrvatske o uvođenju radne obveze doktorima medicine u bolničkim zdravstvenim ustanovama (NN, br. 137/13).

16 Vidi Odluku i Rješenje br. U-II 2064/2010 od 23. V. 2018. (NN, br. 51/18), tč. 15. obrazloženja.

17 ZSDU/19, Dio četvrti, čl. 39. i 40.

18 Vidi napomenu o svrsi i pravnoj prirodi naredbe u Ivančević, op. cit., str. 48, slično i Perić, Berislav, Struktura prava, Informator, Zagreb, 1994., str. 143. S tim u vezi treba istaknuti da naš klasik Krbek u monografiji Sudska kontrola naredbe, Jugoslavenska akademija znanosti i umjetnosti, Tisak zaklade tiskare Narodnih novina, 1939., pod „naredbom“ ne razumijeva naredbu kao specifičnu vrstu podzakonskog akta koju tu razmatramo, nego kao „uredbu“ (u smislu uredbi po neposrednoj ustavnoj ovlasti, uredbi iz nužde, uredbi po zakonskoj ovlasti te uredbi za izvršenje zakona), odnosno podzakonski općenormativni akt u širem smislu. Tako i Babac, Branko, „Ogled o obnovi naučavanja o naredbi u hrvatskim upravnim znanostima“, Pravni vjesnik, 15(1-2), 1999., str. 65-122.

19 Zakon o sustavu državne uprave (NN, br. 150/11, 12/13, 93/16, 104/16), čl. 1.,18. i 19.

20 Zakon o sustavu državne uprave (NN, br. 75/93, 92/96, 48/99, 15/00, 59/01, 199/03, 79/07), čl. 1., 17. i 18 . 
koja su gotovo bez iznimke formulirana na način koji naredbodavcu omogućuje pravodobno normiranje različitih izvanrednih situacija, u okviru kojih se naređuje neko postupanje ili propuštanje koje inače nije obvezatno ili se zabranjuje neko postupanje koje je inače zakonom dopušteno, ${ }^{21}$ pri čemu su nerijetko korištene i sasvim općenite formulacije, bez jasno utvrđenih granica ovlasti. ${ }^{22}$ Naredbe koje se donose na temelju takvih ovlaštenja pretežito sadržavaju imperativne norme koje gotovo bez iznimke djeluju restriktivno i na poslovanje trećih osoba. ${ }^{23} \mathrm{Kad}$ je riječ o adresatima naredbi, dosadašnja praksa pokazuje da se najčešće radi o pravnim i fizičkim osobama - gospodarskim subjektima čije se poslovanje primarno odvija u tehnički složenijim područjima koja uz razvoj tehnologije podliježu sve detaljnijoj regulaciji, upravo zbog potencijalno štetnih učinaka na život ili zdravlje širokog kruga građana, kao što su, zdravstvo, poljoprivreda ili zaštita prirode i okoliša, a kojima se za trajanja interventne mjere ograničava kakvo na temelju zakona stečeno pravo, nameće kakva dodatna obveza ili trpljenje. Valja dodati i to da je, iako tu definitivno nije riječ o iznimnim stanjima (stanjima nužde) na koje se odnose odredbe članka 101. Ustava, u kontekstu supra iznesenog, razvidno da kod primjene naredbodavnih ovlaštenja također dolazi do odstupanja od pravila koja vrijede za normalna stanja, odnosno do modifikacije načela zakonitosti, ${ }^{24}$ pri čemu postoji ,jaka prevaga javnog interesa koja dopušta jače državne zahvate, snažnije državne mjere, jači stupanj jednosmjernosti vlasti, značajnije pojednostavljivanje interesnih odnosa u društvu i veći opseg ograničenja pojedinačnih i kolektivnih prava no što je to u "normalnom" stanju". ${ }^{25}$ Osiguranje adekvatne kontrole ustavnosti i zakonitosti naredbe stoga je nužno ne samo zbog zaštite objektivnog pravnog poretka koji, po

21 Vidi naredbodavna ovlaštenja u Zakonu o zaštiti prirode (NN, br. 80/13, 15/18, 14/19), čl. 55. st. 4. i čl. 63. st. 1. i Zakonu o suzbijanju zlouporabe droga (NN, br. 107/01, 87/02, 163/03, 141/04, 40/07, 149/09, 84/11, 80/13, 39/19), čl. 50a st. 1

22 Osobito je to slučaj u upravnim područjima čija je regulacija usko vezana uz provedbu pravno obvezujućih akata Europske unije, vidi ovlaštenja sadržana u Zakonu o hrani (NN br. 81/13, 14/14, 30/15, 115/18), čl. 3. st. 4. i 5., Zakonu o prehrambenim aditivima, aromama i prehrambenim enzimima (NN, br. 39/13, 114/18) čl. 3. st. 3., Zakonu o provedbi Uredbe (EZ) br. 648/2004 Europskoga parlamenta i Vijeća od 31. ožujka 2004. godine o deterdžentima (NN, br. 34/12, 25/13 i 114/18), čl. 3. st. 4., Zakonu o informiranju potrošača o hrani (NN, br. 56/13, 14/14, 56/16, 32/19), čl. 4. st. 4., Zakonu o službenim kontrolama koje se provode sukladno propisima o hrani, hrani za životinje, o zdravlju i dobrobiti životinja (NN, br. 81/13, 14/14, 56/15, 32/19) čl. 3. st. 2. i 3. i Zakonu o provedbi Uredbe (EZ) br. 1107/2009 o stavljanju na tržište sredstava za zaštitu bilja (NN, br. 80/13, 32/19), čl. 3. st. 3. i 4.

23 Pored javnopravnih tijela koja je neposredno izvršavaju, u krugu adresata naredbe nužno su i treće osobe, vidi Naredba o stavljanju na tržište upaljača sigurnih za djecu i zabrani stavljanja na tržište upaljača »noviteta« (NN, br. 19/11, 54/11, 40/12, 58/13, 57/14, 26/15, 71/16), Naredba o zabrani uporabe didušikovog monoksida (NN, br. 69/19), Naredba o mjerama za sprečavanje pojave i ranog otkrivanja unosa virusa afričke svinjske kuge na području Republike Hrvatske (NN, br. 111/18), Naredba o mjerama zaštite zdravlja životinja od zaraznih i nametničkih bolesti i njihovom financiranju u 2019. godini (NN, br. 5/19)

24 „S gledišta ustavnosti i zakonitosti radi se o modifikacijama postojećeg poretka stvaranjem specifičnog ali pravno uređenog poretka koji bi trebao prestati i omogućiti povratak ranijem stanju čim se normaliziraju prilike“, prema Ivančević, op. cit., str. 109, vidi i Borković, op. cit., str. 77.

25 Omejec, „Hrvatska uprava - od socijalističkog do europskog koncepta zakonitosti“, str. 23. O izvanrednim stanjima u pravnoj teoriji (u komparativnom kontekstu) opširnije u id., ,Izvanredna stanja u pravnoj teoriji i ustavima pojedinih zemalja“, Pravni vjesnik, 12(1-4) 1996., str. 175-179. Daljnje razmatranje naredbodavnih ovlaštenja u tom kontekstu bi, međutim, značajno prešlo ograničene okvire ovoga članka. 
sili ustava, u svim svojim hijerarhijskim stupnjevima mora biti sadržajno usklađen, ${ }^{26}$ nego i zbog zaštite temeljnih prava i sloboda u koje neke naredbe, što ćemo infra pokazati, s obzirom na sadržaj i svrhu naredbodavnog ovlaštenja, neposredno zadiru.

\section{KLJUČNE NOVINE I (STARI) PROBLEMI U SUSTAVNOM UREĐENJU NAREDBE}

Najznačajnije novine koje je ZSDU/19 donio u tom pogledu moguće je sumirati na to da su normativna ovlaštenja konačno sistematizirana zasebno od izvornih poslova državne uprave te dodatno razgraničena na ovlaštenja za donošenje provedbenih propisa - pravilnika (kojima se detaljnije razrađuju pojedine odredbe zakona radi njihove primjene) i naputaka (kojima se detaljnije propisuje način obavljanja poslova državne uprave) - i ovlaštenja za donošenje naredbi, kojima se naređuje ili zabranjuje određeno postupanje i utvrđuju druge privremene interventne mjere. Za potonje je konačno izričito utvrđena i svrha („,trenutačna zaštita pravnog poretka te zaštita života, sigurnosti, zdravlja stanovništva ili imovine veće vrijednosti u određenom upravnom području“). Treba istaknuti da su ključni argumenti (uključujući i neke eksplicitne upute zakonodavcu) za takvo uređenje naredbodavnih ovlaštenja, a time i za izdvajanje naredbe iz kruga provedbenih propisa, izloženi još u Odluci br. U-I-3845/2006 gdje je Ustavni sud, primarno adresirajući ustavnopravno dvojbene situacije sa stupanjem na snagu provedbenih propisa prije njihove objave u Narodnim novinama, zauzeo sljedeća stajališta:

Administrativna praksa pokazuje da su se pod naredbe u smislu čl. 18. ZoSDU/93 (odnosno čl. 19. ZoSDU/11) podvodile (i da se dalje podvode) "naredbe" koje su po svojoj pravnoj prirodi interventne mjere. (...). Objava takvih interventnih mjera, iako obvezna, po prirodi stvari može biti samo naknadna. Administrativna je praksa, međutim, zbog nedostatno razrađenih zakonskih normi takve mjere podvela pod "naredbu" iz čl. 18. st. 2. ZoSDU/93 odnosno čl. 19. st. 2. ZoSDU/11 i na taj način na njih protegnula režim "drugih propisa državnih tijela" u smislu čl. 90. st. 1. Ustava (...). Došlo je vrijeme da se takva administrativna praksa napusti i da se to pravno područje uskladi s načelom vladavine prava, najviše vrednote ustavnog poretka Republike Hrvatske, radi ostvarenja sigurnosti objektivnog pravnog poretka. Ustavni sud u tom smislu utvrđuje da se državne interventne mjere po naravi stvari, zbog svoga cilja i svrhe kojoj služe, ne mogu smatrati drugim propisima u smislu čl. 90. st. 1. Ustava uz koje se vezuje zakonom propisano sedmodnevno vakacijsko razdoblje koje se računa od prvog dana nakon njihove objave u "Narodnim novinama". Sukladno tome, njihovo su donošenje i provedba s ciljem trenutačne zaštite slobode, prava drugih ljudi, pravnog poretka, javnog morala ili zdravlja stanovništva izvan dosega čl. 19. st. 4. ZoSDU/11 i ne mogu se poistovjećivati ni s jednom vrstom podzakonskih akata na koje se te zakonske odredbe odnose. Zakonodavac je stoga u ZoSDU/11, kao općem zakonu koji uređuje sustav

26 Prema Omejec, „O potrebnim promjenama u strukturi hrvatskog ustavnog sudovanja (prilog reformi ustavnog sudovanja)“ u: Barbić, Jakša (ur.), Zbornik radova s okruglog stola Hrvatske akademije znanosti $i$ umjetnosti: Hrvatsko ustavno sudovanje de lege lata i de lege ferenda, Hrvatska akademija znanosti i umjetnosti, Zagreb 2009., str. 48. 
državne uprave, dužan razgraničiti interventne mjere od "drugih propisa državnih tijela" u smislu čl. 90. st. 1. Ustava i čl. 19. ZoSDU/11, propisati vrijeme njihova stupanja na snagu te vrijeme i način njihove objave, ali i opće pretpostavke pod kojima je u pravnom poretku Republike Hrvatske državnoj upravi dopušteno izdavati takve mjere. Kad je riječ o ograničavanju sloboda i prava takvim interventnim mjerama, regulatorna obveza zakonodavca proizlazi i iz čl. 16. st. 1. Ustava koji propisuje da se slobode i prava mogu ograničiti "samo zakonom da bi se zaštitilo slobodu i prava drugih ljudi te pravni poredak, javni moral i zdravlje". ${ }^{27}$

Kao značajan iskorak može se izdvojiti i to što je, pored općeg načela zakonitosti (,naredbe donose čelnici tijela državne uprave kada su na to izrijekom zakonom ovlašteni, u granicama dane ovlasti“c), odredbom članka 39. stavka 2. ZSDU/19 izrijekom utvrđeno da (ovlašćujućim) zakonom moraju biti propisani i uvjeti za donošenje naredbe, kao i vremenski i materijalni opseg zabrane, obveze ili druge privremene interventne mjere koja se naredbom utvrđuje. ${ }^{28}$ Zadržavanje tih pitanja u okvirima parlamentarnog rezervata dosljedno je supra citiranom stajalištu Ustavnog suda prema kojem je zakonodavac dužan propisati „opće pretpostavke pod kojima je u pravnom poretku Republike Hrvatske državnoj upravi dopušteno izdavati takve mjere", jer isključuje podzakonsko normiranje sadržaja ili trajanja naredbe temeljem koje se stečena prava ili obveze u određenom, makar vremenski ograničenom razdoblju, tretiraju drugačije nego što je ta pitanja uredio zakonodavac (neposredni contra legem učinak). ${ }^{29}$

Postavlja se pitanje, međutim, može li zakonska determiniranost uvjeta i opsega ovlaštenja sama po sebi biti dovoljna zaštita od arbitrarnosti i posljedičnog narušavanja temeljnih elemenata vladavine prava, poput pravne sigurnosti i jednakosti pravnih

27 Prema tč. 18-20. obrazloženja Odluke br. U-I-3845/2006. Na istom mjestu Ustavni sud, vezano uz dotadašnju praksu skraćivanja vakacijskog roka naredbe navodi i sljedeće: „Pogrešno podvođenje interventnih mjera pod naredbu iz čl. 19. st. 4. ZoSDU/11 (nekadašnjeg čl. 18. st. 4. ZoSDU/93) u praksi je stvaralo dojam da je riječ o očito neustavnim situacijama. Tako je, primjerice, Naredba o mjerama za sprječavanje pojave i širenja klasične svinjske kuge na području Republike Hrvatske (NN, br. 32/09.) na temelju točke V. stupila na snagu "odmah" (2. ožujka 2009.), iako je objavljena u Narodnim novinama tek 13. ožujka 2009.; Naredba o zabrani uvoza u Republiku Hrvatsku i provoza preko područja Republike Hrvatske peradi i proizvoda od peradi radi sprječavanja unošenja influence ptica (NN br. 70/ 08.) na temelju točke IV. stupila je na snagu "odmah" (6. lipnja 2008.), iako je objavljena u Narodnim novinama tek 18. lipnja 2008., itd. Prema tome, kad bi se te interventne mjere smatrale "naredbama" iz čl. 19. st. 4. ZoSDU/11, njihova bi nesuglasnost s čl. 90. st. 1. Ustava bila očita: one bi stupale na snagu prije no što bi bile objavljene u Narodnim novinama.“.

28 Prema čl. 39. st. 2. ZSDU/19. Valja, međutim, primijetiti da je zakonodavac propustio isto učiniti i u čl. 38. ZSDU/19 kojim su propisani krug mogućih ovlaštenika i opći uvjeti za donošenje provedbenih propisa, uslijed čega su takva ovlaštenja i dalje vezana tek općim načelom zakonitosti, odnosno ovlašteni subjekti provedbene propise donose „kada su izrijekom zakonom ovlašteni, u granicama dane ovlasti“, što samo po sebi ne može poslužiti kao osobita smjernica za formulaciju ovlašćujućih odredbi niti sprečava zakonodavca da te granice utvrdi razmjerno široko.

29 U literaturi se, pored zakonskog primata te načela zakonitosti u užem smislu, kao temeljni ratio zakonskog i parlamentarnog rezervata ističe očuvanje načela demokratičnosti, odnosno narodnog suvereniteta, kao i načela diobe vlasti u kontekstu sve složenijih gospodarskih i društvenih odnosa, vidi Barić, op. cit., str. 127, vidi i Ossenbühl, Fritz, ,Vorrang und Vorbehalt des Gesetzes“, u: Isensee, Josef i Kirchof, Paul (ur.), Handbuch des Staatsrechts der Bundesrepublik Deutschland, Band V, Rechtsquellen, Organisation, Finanzen, C.F. Müller, Heidelberg, 2007., str. 192, 204-206. 
subjekata pred zakonom. ${ }^{30}$ Smatramo da je odgovor negativan, jer izvan domašaja načela zakonitosti ostaju, primjerice, naredbodavna ovlaštenja kojima su nepobitno utvrđeni sadržaj, trajanje i opseg neke privremene zabrane ili dodatne obveze, a kojima se, upravo s obzirom na njihov sadržaj i opseg, neposredno zadire u pojedina temeljna prava i slobode, kao što su sloboda kretanja, ili pak poduzetnička i tržišna sloboda i/ili vlasnička prava. ${ }^{31}$ Štoviše, to naredbodavno ovlaštenje može biti disjunktivno (,u slučaju x ministar može naredbom zabraniti“), a „uvjeti za donošenje“ naredbe mogu, svjesno ili ne, biti određeni na način koji naredbodavcu ostavlja (pre)širok prostor slobodne prosudbe da zabranjuje (ili nameče/naređuje) određeno postupanje kad god smatra „da su se stekli uvjeti propisani člankom x ovoga Zakona“, ili „da je to nužno/potrebno za provedbu odredbi ovoga Zakona“. Potonji je slučaj osobito problematičan s konstitucionalističkog gledišta jer se radi o općem naredbodavnom ovlaštenju s neposrednim (restriktivnim) učinkom na temeljna prava i slobode. ${ }^{32}$

Pored navedenoga, činjenica je da se nikakvom zakonodavnom tehnikom ne mogu unaprijed isključiti pogreške u tumačenju širine ovlaštenja koje bi u konačnici (svjesno ili ne) mogle rezultirati nametanjem zabrana ili obveza izvan granica zakonske ovlasti ili opterećivanjem gospodarskih subjekata koje je sasvim nerazmjerno svrsi donošenja određene naredbe ili, što bi bio osobito ekstreman (ali ne i nezamisliv) slučaj, donošenjem takve naredbe s povratnim djelovanjem. ${ }^{33}$ $\mathrm{S}$ tim u vezi treba istaknuti da je kontrola objektivne ustavnosti ovlaštenja za

30 Pod formalnim elementima vladavine prava tu razumijevamo njezine temeljne vrijednosti $u$ formalnom smislu kao što su ustavnost i zakonitost, koherentnost pravnog poretka, jednakost pravnih subjekata pred zakonom, pravna sigurnost i predvidljivost djelovanja državne vlasti, vidi Barić, op. cit., str. 227, 230, Smerdel, op. cit., str. 8-9, 121-122., Lauc, Zvonimir, „Načelo vladavine prava u teoriji i praksi“, Pravni vjesnik, 32(3-4), 2016., str. 51, Omejec, „Hrvatska uprava“, cit., str. 12. To su ujedno i dodirne točke tradicionalnog anglosaksonskog koncepta vladavine prava (rule of law, government under law) i kontinentalnog koncepta pravne države (Rechtstaat, État de droit, stato di diritto), vidi Čepulo, Dalibor, ,Vladavina prava i pravna država - europska i hrvatska pravna tradicija i suvremeni izazovi“", Zbornik Pravnog fakulteta u Zagrebu, 61(6), 2001., str. 1343, opširnije u Bačić, Arsen, „Vladavina prava i institucije kontrole ustavnosti zakona“, u: Crnić, Jadranko i Filipović, Nikola (ur.), Ustavni sud u zaštiti ljudskih prava, Organizator, Zagreb, 2000, str. 29-37. O utjecaju ovih koncepata na razvoj izvornih i delegiranih ovlasti uprave u SAD i SR Njemačkoj opširnije u Hamburger, Philip, Is Administrative Law Unlawful?, University of Chicago Press, Chicago/London, 2014., str. 471-477.

31 Radi se o pravima i temeljnim slobodama zajamčenima Ustavom, koja se mogu iznimno ograničiti zakonom, ako je to nužno radi zaštite pravnog poretka, ili zdravlja, prava i sloboda drugih (sloboda kretanja čl. 32. st. 2. Ustava), odnosno, radi zaštite interesa i sigurnosti Republike Hrvatske, prirode, ljudskog okoliša i zdravlja ljudi (poduzetnička sloboda i vlasnička prava, čl. 50. st. 2. Ustava), vidi i Smerdel, op. cit., str. 304. Valja istaknuti da se vlasništvo u smislu čl. 48. st. 1. Ustava u našoj ustavnosudskoj praksi ustaljeno interpretira tako da obuhvaća „načelno sva imovinska prava“, vidi tč. 15. Odluke br. U-I2813/2014 od 3. VI. 2016.

32 Izraz opće (generalno) ovlaštenje za potrebe ovog rada koristimo u smislu zakonskog ovlaštenja za donošenje nesamostalnih spontanih podzakonskih općenormativnih akata u određenom području, gdje se nositelj ovlaštenja ,može koristiti ovlaštenjem da donosi tu vrstu podzakonskih općenormativnih akata djelujući spontano, tj. ne čekajući nikakvu novu, posebnu ovlast u nekoj drugoj pravnoj normi“, prema Borković, op. cit., str. 103-104, vidi i Ivančević, op. cit., str. 94, Perić, op. cit., str. 139.

33 Tu ciljamo na pravu retroaktivnost koja je kod podzakonskih akata izrijekom isključena člankom 90. Ustava. S druge strane, „neprava ili kvaziretroaktivnost“, kod koje se novo pravno pravilo primjenjuje na odnose kreirane pravnim aktima ili poslovima nastalima prije njegova stupanja na snagu, ali su ti odnosi još uvijek pravno egzistentni odnosno u tijeku svoje realizacije, kod naredbi se po prirodi stvari ne može isključiti. Za mjerodavno ustavnosudsko stajalište o pitanju neprave retroaktivnosti vidi Rješenje br. U-I-4455/2015 od 4. IV. 2017. 
donošenje naredbi nedvojbeno u jurisdikciji Ustavnog suda, no, imajući u vidu da je naredba u ZSDU/19 izdvojena iz kruga provedbenih propisa, odnosno da se u tom zakonu nigdje izričito ne utvrđuje da je naredba „propis“, ostalo je otvoreno pitanje nadležnosti za kontrolu objektivne ustavnosti i zakonitosti samih naredbi. Naime, kontrolu zakonitosti naredbe u ovom trenutku definitivno nije moguće osigurati u okviru objektivnog upravnog spora čiji je predmet isključivo kontrola zakonitosti općeg akta jedinice lokalne i područne (regionalne) samouprave, pravne osobe s javnim ovlastima i pravne osobe koja obavlja javnu službu. ${ }^{34}$ Ako bi se i Ustavni sud povodom nekog budućeg zahtjeva ili prijedloga za ocjenu ustavnosti ili zakonitosti naredbe oglasio nenadležnim, uz obrazloženje da je naredba izdvojena iz kruga provedbenih propisa te stoga nije „drugi propis“, to bi dovelo do ustavnopravno neprihvatljive situacije da niti jedno državno (nepolitičko) tijelo nije ovlašteno za ukidanje (ili poništavanje) nezakonite/neustavne naredbe..$^{35}$

U nastavku rada stoga ćemo pobliže adresirati sljedeće pitanje: koja su temeljna materijalna obilježja naredbe i što nam ta obilježja, u korelaciji sa svrhom donošenja, okvirnim sadržajem i općim vremenskim i materijalnim ograničenjima naredbe govore o pravnoj prirodi toga podzakonskog akta, odnosno postoji li teorijsko uporište za sistematizaciju naredbe među normativna ovlaštenja, imajući u vidu da se više ne radi o provedbenom propisu. U završnom ćemo dijelu pak pobliže razmotriti otvoreno pitanje nužnog stupnja određenosti i preciznosti ovlašćujuće norme koja zadire u temeljna prava i slobode i primjenu načela razmjernosti u prevenciji općih naredbodavnih ovlaštenja, odnosno nužnom limitiranju normativne autonomije zakonodavca i naredbodavca te, zaključno, treba li naredba, imajući u vidu sve izneseno, biti predmet ustavnosudske kontrole ustavnosti i zakonitosti.

\section{PRAVNA PRIRODA I TEMELJNA OBILJEŽJA NAREDBE}

Kad je riječ o pravnoj prirodi i temeljnim materijalnim obilježjima naredbe, nedvojbeno je da se radi o eksternom aktu pravno obvezujućeg karaktera, ili, preciznije, podzakonskom aktu s neposrednim pravnim učinkom na treće osobe. Naredba redovito sadrži generalna pravila ponašanja, imajući u vidu da su u krugu subjekata kojima se obraća pravni imperativ tog akta sve pravne i fizičke osobe koje se nađu u pravnoj situaciji da se određena naredba na njih ima odnositi. ${ }^{36}$ Postavlja

34 Prema čl. 3. st. 2. Zakona o upravnim sporovima (NN, br. 20/10, 143/12, 152/14, 94/16, 29/17). Imajući to u vidu, Visoki upravni sud eventualni bi zahtjev za ocjenu zakonitosti naredbe mogao jedino odbaciti.

35 Namjerno ističemo ,nepolitičko“ imajući u vidu da nadzor zakonitosti postupka donošenja i sadržaja naredbi koji je prema čl. 41. ZSDU/19 ovlaštena provoditi Vlada ne služi zaštiti objektivnog pravnog poretka nego je po svojoj prirodi političko-instancijskog karaktera te ga stoga u okviru ovoga rada ne razmatramo.

36 Za razliku od konkretnih (pojedinačnih) pravnih akata poput rješenja ili presude, naredba se nikada ne upućuje konkretnim osobama. 
se pitanje, možemo li temeljem navedenog o naredbi govoriti kao o „apstraktnom i generalnom pravilu ponašanja - općoj normativnosti“ ${ }^{37}$ odnosno, poslužimo li se ustavnosudskom definicijom drugog propisa, kao o „eksternom općenormativnom i pravno obvezujućem aktu koji je donijelo tijelo državne vlasti radi uređenja pojedinih pitanja, izvršenja i/ili provedbe zakona, odnosno provedbe drugog propisa više pravne snage, koji uređuje odnose na općenit način i koji djeluje prema svima koji se nađu u pravnoj situaciji da se na njih dotični akt ima primijeniti“ “. ${ }^{38}$ Tu već situacija postaje složenija jer se niti jedan pravno obvezujući akt kojim se utvrđuju privremene interventne mjere, pristupimo li tom teorijskom pitanju restriktivno, ne bi trebao smatrati zakonom u materijalnom smislu, imajući u vidu da se dispozicija takvog akta - naređivanje ili zabrana određenog postupanja, ili što drugo - po prirodi stvari odnosi isključivo na neko incidentno odstupanje od redovitog stanja - bez obzira na trajanje, intenzitet a time i opći značaj tog konkretnog slučaja, odnosno njegov neposredni učinak na vrlo širok krug subjekata. Štoviše, i dosadašnja je naredba u literaturi definirana kao ,propis uprave koji sadrži naređenja ili zapovjedi za određenu situaciju koja ima opći značaj“, odnosno „propis kojim se uređuje jedna konkretna situacija na opći način" ${ }^{39} \mathrm{~S}$ druge strane, uzmemo li u obzir dosadašnju naredbodavnu praksu, činjenica je da u trenutku donošenja naredbe ne mora biti izvjesno (najčešće i nije) na koliko će se slučajeva njezin pravni imperativ odnositi, niti je to uvijek moguće (ni poželjno) unaprijed odrediti, ${ }^{40}$ dok opći značaj okolnosti na koje se taj imperativ odnosi u pravilu preteže nad incidentnom (konkretnom) naravi tih okolnosti. ${ }^{41}$ Slijedom iznesenoga, stajališta smo da se naredbu može smatrati podzakonskim općenormativnim aktom, odnosno podzakonskim aktom koji sadrži i generalna i apstraktna pravila ponašanja.

Neki opći zaključci o stupnju sadržajne vezanosti naredbe za ovlašćujući zakon, a i o naravi takvog zakonskog ovlaštenja mogu se izvesti već iz formulacije članka 39. ZSDU/19, ali i iz dosadašnje zakonodavne prakse u kojoj su se ta ovlaštenja pretežito formulirala na način koji naredbodavcu omogućuje privremeno normiranje izvanrednih situacija. U osnovi, izvršna klauzula ovlašćujućeg zakona konstituira nadležnost za donošenje naredbe kojom će se, ako se za to steknu propisani uvjeti, narediti postupanje ili propuštanje koje inače nije obvezatno, dakle utvrdit će se nova, dodatna pravila (praeter legem učinak) ili će se zabraniti postupanje koje je inače zakonom dopušteno (contra legem učinak). ${ }^{42}$ Naredbodavno ovlaštenje

37 Prema Ivančević, op. cit., str. 85.

38 Prema Rješenju br. U-II-5157/2005.

39 Vidi „,naredba“ u: Vidaković Mukić, Marta, Opći pravni rječnik, Narodne novine, Zagreb, 2006. str. 593, vidi i Ivančević, op. cit., str. 48.

40 Vidi, primjerice, Naredba o poduzimanju mjera obveznog uklanjanja ambrozije (NN, br. 72/07) i Naredba o privremenim mjerama u odnosu na sadržaj aflatoksina M1 u mliječnim proizvodima (NN, br. 39/13).

${ }^{41}$ Nije rijetkost ni da se zakoni donose povodom nekog konkretnog slučaja ili radi regulacije nekog konkretnog pitanja, s unaprijed ograničenim vremenskim učinkom, vidi Zakon o otpisu dugova fizičkim osobama (NN, br. 62/18), osobito čl. 2. i 13.

42 O pravnoj prirodi izvršne klauzule općenito u Ivančević, op. cit., str. 92-93, vidi i Perić, op. cit., str. 140 
može biti formulirano i kao kategoričko/obligatorno (,,u slučaju x ministar će naredbom zabraniti“) i kao disjunktivno/fakultativno (,u slučaju x ministar može naredbom narediti“ $),{ }^{43}$ no treba istaknuti da ni u jednom od ta dva slučaja primjena dispozicije ovlaštenja (donošenje naredbe) nije u potpunosti izraz autonomne volje zakonodavca ili naredbodavca, nego je izrijekom uvjetovano vanjskim činjenicama - nastankom osobito incidentnih prirodnih ili društvenih okolnosti koje zahtijevaju trenutačno djelovanje izvršnog autoriteta radi zaštite pravnog poretka te zaštite života, sigurnosti, zdravlja stanovništva ili imovine veće vrijednosti u određenom upravnom području. Odabir vrste ovlaštenja ovisi pak prvenstveno o percipiranom stupnju ugroze koju neki takav događaj ili stanje predstavljaju.

Zadržavanje naziva i dosadašnje sadržajne odrednice (,naređivanje ili zabrana određenog postupanja“) upućuju nas na to da je zakonodavac svjesno naglasio autoritativno-represivan učinak naredbi, koje će, sasvim je izvjesno, i ubuduće sadržavati imperativne (kogentne) norme čiju primjenu njezini adresati ne mogu otkloniti svojom voljom, a koje u pravilu djeluju restriktivno, odnosno opterećujuće na poslovanje trećih osoba. ${ }^{44}$ Međutim, budući da je sada riječ o aktu koji se donosi isključivo radi uređivanja zakonom određenih incidentnih situacija, koje po prirodi stvari ne mogu, ne bi trebale ili ne bi smjele imati trajni karakter, takav će učinak naredbe biti unaprijed vremenski ograničen i to ovisno o stipulaciji ovlašćujuće odredbe, trajanjem konkretne incidentne situacije ili kalendarski. ${ }^{45}$

Što se tiče stupanja na snagu i načina publikacije, naredbe su odredbom članka 39. stavka 3. ZSDU/19 izričito izuzete od pravila o najkraćem dopuštenom vakacijskom razdoblju koja vrijede za provedbene propise, ${ }^{46}$ tako da one mogu (ali i ne moraju) stupiti na snagu danom donošenja, dok je uz obvezu njihove objave u Narodnim novinama propisana i objava ,putem drugih dostupnih sredstava javnog priopćavanja“. Za pretpostaviti je da je temeljni ratio takvog uređenja bio omogućiti pravodobnu reakciju naredbodavca na osobito incidentne situacije koje bi trebale biti predviđene hipotezom zakonskog ovlaštenja (o čemu opširnije infra), s tim da je već sada izvjesno da će kod naredbi koje će stupiti na snagu danom donošenja, njihova objava ,putem drugih dostupnih sredstava javnog priopćavanja“ prethoditi objavi u Narodnim novinama. S tim u vezi, iako zakonodavčev pristup načelno jest dosljedan stajalištu Ustavnog suda da „objava takvih interventnih mjera, iako obvezna, po prirodi stvari može biti samo naknadna“" ${ }^{47}$ mišljenja smo da bi de lege ferenda, a imajući u vidu supra opisanu pravnu prirodu i učinke naredbi, prikladnije bilo kao opće pravilo propisati da se naredbe objavljuju u Narodnim novinama te stupaju na snagu najranije prvoga dana od dana objave, a kao iznimku propisati

43 Vidi Zakon o zaštiti prirode, gdje čl. 55. st. 4. i čl. 63. st. 1. sadrže kategorička, a čl. 164. st. 3. i čl. 152. st. 2. i 3. disjunktivna ovlaštenja, kao i čl. 52. st. 5. Zakona o zaštiti životinja (NN, br. 102/17, 32/19).

44 Vidi naredbe navedene supra u bilj. 23.

45 U potonjem slučaju, ako incidentna situacija i dalje perzistira u trenutku kad je naredba silom zakona prestala važiti, ovlašteni naredbodavac uvijek može donijeti novu naredbu istoga sadržaja.

46 Za mjerodavno stajalište o najkraćem dopuštenom vakacijskom razdoblju za provedbene propise (prvog dana od dana objave) vidi tč. 14.1. i 14.2. obrazloženja Rješenja br. U-II-3104/2014 od 8. XI. 2016.

47 Prema tč. 18.1. obrazloženja Odluke br. U-I-3845/2006. 
da iz osobito opravdanih (i zakonom propisanih) razloga naredbe mogu stupiti na snagu danom objave, u kojem slučaju ih je donositelj dužan bez odgađanja objaviti i putem drugih dostupnih sredstava javnog priopćavanja.

U ovoj je fazi, imajući u vidu prethodna izlaganja o pravnoj prirodi i temeljnim materijalnim obilježjima naredbe, moguće odgovoriti i na pitanje postoji li teorijsko uporište za zakonsku sistematizaciju naredbe među normativna ovlaštenja. Kao što smo uvodno istaknuli, sva normativna ovlaštenja naših upravnih tijela u osnovi su delegirana ovlaštenja. Promotrimo li naredbodavna ovlaštenja u kontekstu normativne delegacije, može se doći do zaključka da su osnovne faze, subjekti i obilježja delegacije istovjetni kao i kod zakonskih ovlaštenja za donošenje provedbenih propisa. Naime, zakonodavac (delegant) jednostranom izjavom volje - ovlašćujućim zakonom - autonomno odlučuje o nastanku, sadržaju, opsegu, usmjerenju i trajanju naredbodavne ovlasti. ${ }^{48}$ Stupanjem na snagu ovlašćujućeg zakona, naredbodavac (delegatar) stječe novu normativnu ovlast koju izvorno nema, pri čemu je zakonodavac i nadalje u mogućnosti zakonom u cijelosti normirati istu materiju (neovisno o maloj praktičnoj vrijednosti toga pravila), ${ }^{49}$ a naredbodavnu ovlast u svakom trenutku izmijeniti u sadržaju i opsegu, ili je sasvim ukinuti (opozvati) donošenjem novog akta iste pravne snage, odnosno neovlašćujućeg zakona, bez naredbodavčeva pristanka. ${ }^{50}$ Naredbodavna ovlast sadržajno je uža od izvorne ovlasti deleganta, omeđena granicama naredbodavčevog djelokruga te dodatno limitirana općim materijalnim granicama delegacije utvrđenima ustavom, ustavnosudskom praksom i delegirajućim zakonom. ${ }^{51}$ Slijedom iznesenoga, mišljenja smo da je sistematizacija naredbi među normativna ovlaštenja teorijski utemeljena i stoga opravdana.

\section{NOSITELJI NAREDBODAVNIH OVLAŠTENJA}

Znakovito je da se kao potencijalni nositelji naredbodavnih ovlaštenja odredbom članka 40. ZSDU/19 utvrđuju isključivo čelnici tijela državne uprave, dakle ministri i drugi državni dužnosnici koji upravljaju državnim upravnim organizacijama. ${ }^{52}$ Intenciju zakonodavca, da se krug mogućih naredbodavaca time ograniči na politički imenovane dužnosnike, moguće je iščitati iz toga što isti članak ne predviđa iznimku kakva je člankom 38. utvrđena za provedbene propise, za čije je donošenje moguće

48 Jednako kao i pri zakonodavnoj delegaciji, vidi Barić, op. cit., str. 52. Budući da je objekt svake normativne delegacije - u osnovi - ovlast za jednostrano uređivanje društvenih odnosa putem formalnih, općeobvezujućih pravnih akata - naredbodavna ovlast jest delegirana normativna ovlast.

49 Svaka materija/incidentna situacija koja može biti predmet normiranja putem neke naredbe može biti predmet normiranja i putem zakona, vidi supra spomenute zakone koji se donose povodom konkretnog slučaja ili radi regulacije nekog konkretnog pitanja, s unaprijed ograničenim vremenskim učinkom.

50 Zbog moguće opozivosti svaka normativna delegacija (bar nominalno) ima privremeni karakter, vidi Barić, op.cit., str. 52-54, 56.

51 O primjenjivim ograničenjima opširnije infra.

52 Prema čl. 59. st. 1. ZSDU/19 to je glavni ravnatelj za državne zavode, državne uprave i državna ravnateljstva, glavni državni inspektor za državne inspektorate te državni tajnik za središnje državne urede. 
posebnim zakonom ovlastiti i tijela pravnih osoba s javnim ovlastima, ako je to nužno za preuzimanje ili osiguravanje provedbe pravno obvezujućih akata EU-a. Ako će i zakonodavna praksa ovu odredbu tretirati kao numerus clausus, to će onemogućiti fenomen prebacivanja odgovornosti za donošenje nepopularnih (politički štetnih) interventnih mjera u području reguliranih javnih usluga s resornih ministara na politički formalno neodgovorne članove regulatornih vijeća. ${ }^{53} \mathrm{~S}$ druge strane, ako se neko naredbodavno ovlaštenje odnosi na upravno područje u djelokrugu više tijela državne uprave, odnosno ako je za dio upravnog područja koje se privremeno uređuje naredbom stvarno nadležno drugo tijelo državne uprave, naredbodavna ovlast ograničava se prethodnom suglasnošću čelnika toga tijela, ${ }^{54}$ uslijed čega će se i politička odgovornost podijeliti na najmanje dva državna dužnosnika.

Sam institut prethodne suglasnosti u dijelu četvrtom ZSDU/19 prvi put je cjelovito i sustavno uređen, ${ }^{55} \mathrm{i}$ to uvelike po uzoru na njemačku praksu ograničavanja subdelegiranih ovlaštenja sporazumom (izv. Einvernehmen) s jednim i više saveznih ministra. ${ }^{56}$ Kod naredbodavnih ovlaštenja ograničenih prethodnom suglasnošću ta se suglasnost javlja kao zakonski uvjet za donošenje naredbe - izostanak suglasnosti u trenutku stupanja na snagu naredbe ima za posljedicu njezinu formalnu nezakonitost - te je stoga činjenicu da je prethodna suglasnost dana naredbodavac dužan navesti

53 Teorija o prebacivanju odgovornosti (izv. shifting of responsibility), odnosno prebacivanju i izbjegavanju krivnje (izv. blame shifting) temelji se na politološkoj analizi obrazaca ponašanja (demokratskih) političara koji se, uslijed neizvjesnih ishoda provedbe javnih politika, u bitno većoj mjeri opredjeljuju prema izbjegavanju odgovornosti za posljedice potencijalno neuspješnih javnih politika nego prema preuzimanju rizika i eventualnih zasluga za politike koje se pokažu uspješnima, vidi Fiorina, Morris P., ,Legislative Choice of Regulatory Forms: Legal Process or Administrative Process?" , Public Choice, 39(1), 1982., str. 46-47, vidi i Weaver, Kent R., „,The Politics of Blame Avoidance“, Journal of Public Policy, 6(4), 1986., str. 371-372, Schoenbrod, David, Power Without Responsibility - How Congress Abuses the People Through Delegation, Yale University Press, London, 1993., str. 84-88. Prebacivanjem težišta normativne aktivnosti na politički formalno neovisne subjekte, osobito na formalno nepristrana, profesionalna upravna tijela, mijenja se percepcija vezanosti podzakonske normativne produkcije uz političku volju, kao i percepcija odgovornosti za sadržaj podzakonskih propisa i drugih mjera koje u svrhu regulacije javnih usluga poduzimaju politički neovisni delegatari. O pojavi ovog fenomena u „,novim demokracijama“ srednje i istočne Europe opširnije u Salzberger, Eli M. i Voigt, Stefan, „On Constitutional Processes and the Delegation of Power, with special emphasis on Israel and Central and Eastern Europe“, Theoretical Inquiries in Law, 3(1), 2002., str. 207-263. Za analizu s ekonomskog aspekta vidi Bartling, Björn i Fischbacher, Urs, ,,Shifting the Blame: On Delegation and Responsibility“, The Review of Economic Studies, 79(1), 2012., str. 67-84.

54 Prema čl. 40. st. 2. ZSDU/19, ako se privremene interventne mjere odnose na dio upravnog područja u djelokrugu drugog tijela državne uprave, naredba se donosi uz prethodnu suglasnost čelnika toga tijela.

55 Prema čl. 38. st. 2. i 3. ZSDU/19, Provedbeni propis kojim se uređuje dio upravnog područja u djelokrugu drugog tijela državne uprave donosi se uz prethodnu suglasnost čelnika toga tijela, dok se provedbeni propis kojim se preuzima ili osigurava provedba pravno obvezujućih akata EU-a donosi uz prethodnu suglasnost ministra nadležnog za europske poslove.

56 O prethodnom sporazumu i ostalim oblicima sudjelovanja drugih javnopravnih subjekata $u$ donošenju odluka u njemačkom javnom pravu opširnije u Pünder, Hermann, ,,Verwaltungsverfahren“, u: Erichsen, Hans-Uwe i Ehlers, Dirk (ur.), Allgemeines Verwaltungsrecht, De Gruyter, Berlin, 2011., str. 433-434. U osnovi, ovlaštenje za donošenje uredbe uz sporazum s drugim tijelom ima učinak obvezivanja delegatara na ishođenje prethodne suglasnosti (njezin izostanak za posljedicu ima nezakonitost uredbe) te mora biti izričito utvrđeno u izvršnoj klauzuli delegirajućeg zakona, a ako je ovlast subdelegirana, u jednakoj mjeri obvezuje i primarnog i krajnjeg delegatara, neovisno o postojanju takve odredbe $\mathrm{u}$ subdelegirajućoj uredbi. 
u preambuli naredbe, iza zakonske osnove. ${ }^{57}$ Uskrata prethodne suglasnosti nema učinka na egzistenciju naredbodavnog ovlaštenja, no praktički suspendira donošenje naredbe sve do usuglašavanja njezina sadržaja između naredbodavca i subjekta koji je ovlašten dati prethodnu suglasnost. Budući da ratio ovog instituta nije uskrata suglasnosti koja bi onemogućila korištenje normalnog ovlaštenja, nego ostavljanje prostora za nužno usuglašavanje sadržaja budućeg podzakonskog akta, stajališta smo da svako normativno ovlaštenje uz prethodnu suglasnost drugog tijela implicira i suradnju, odnosno sudjelovanje predstavnika drugog tijela u izradi nacrta odnosnog podzakonskog akta - čime se osigurava prethodna provjera, usklađivanje sadržaja, ali i ekonomičnost procedure, ako je akt potrebno donijeti u osobito kratkom roku, jer će tijelo koje daje suglasnost u tom slučaju već biti u dovoljnoj mjeri upoznato s njegovim sadržajem.

\section{PITANJE NUŽNOG STUPNJA ODREĐENOSTI I PRECIZNOSTI OVLAŠĆUJUĆE NORME I ULOGA NAČELA RAZMJERNOSTI U PREVENCIJI OPĆIH NAREDBODAVNIH OVLAŠTENJA}

Opća ovlaštenja za donošenje podzakonskih općenormativnih akata sama po sebi nisu novost ni rijetkost u našem zakonodavstvu. Primjerice, opća ovlaštenja za donošenje uredbi redovito se koriste pri zakonodavnoj delegaciji (sukladno čl. 88. Ustava) te za uređivanje unutarnjeg ustrojstva tijela državne uprave, gdje njihovo korištenje nije sporno te ih u tom kontekstu dalje ne razmatramo. ${ }^{58} \mathrm{~S}$ druge strane, kad je riječ o provedbenim propisima, opća ovlaštenja najčešća su u upravnim područjima čija je regulacija usko vezana uz preuzimanje ili provedbu pravno obvezujućih akata Europske unije (čije izmjene imaju zasebnu dinamiku), što u ekstremnijim slučajevima pervertira do toga da se u posebne zakone ugrađuju i sasvim neodređene formulacije poput: „ministar je ovlašten donijeti pravilnike, naredbe i naputke za prijenos i provedbu pravno obvezujućih akata Europske unije iz područja koje uređuje ovaj zakon“ ili: „,ministar može pravilnicima, naredbama i napucima uređivati pitanja koja nisu posebno uređena pravno obvezujućim aktima Europske unije iz područja koje uređuje ovaj zakon, u mjeri potrebnoj za njihovu učinkovitu provedbu“ ili čak: „ministar nadležan za (...) ovlašten je pravilnikom, naredbom ili naputkom urediti sva pitanja nužna za provedbu ovoga Zakona“".59 Citirana ovlaštenja osobito su problematična, jer zakonodavac ostavlja neizvjesnim niz bitnih pitanja, čime ministru kao nositelju ovlaštenja prepušta čak i odabir

57 Prema čl. 5. st. 3. Jedinstvenih metodološko-nomotehničkih pravila za izradu akata koje donosi Hrvatski sabor (NN, br. 74/15).

58 Vidi Zakon o ovlasti Vlade Republike Hrvatske da uredbama uređuje pojedina pitanja iz djelokruga Hrvatskog sabora (NN, br. 118/19), čl. 1. i 2., ZSDU/19, čl. 54. st. 1.

59 Vidi ovlaštenja navedena supra $\mathbf{u}$ bilj. 22. 
podzakonskog akta kojim će normirati određeno područje, a time, posljedično i odluku o načinu i intenzitetu, odnosno pravnim učincima podzakonske regulacije. ${ }^{60}$

Stajališta smo da je supra izložene ili slične općenite stipulacije u budućim naredbodavnim ovlaštenjima moguće prevenirati ako zakonodavac pri njihovoj formulaciji, osim općih uvjeta propisanih u ZSDU/19, u dovoljnoj mjeri uvaži i opće zahtjeve za određenošću i preciznošću zakonske norme s restriktivnim učinkom na određena prava i slobode, a potom i ostale elemente načela razmjernosti, koje se u našoj ustavnosudskoj praksi već standardno smatra „odlučnim za ustavnopravno ograničenje prava ili slobode građana““ ${ }^{61} \mathrm{~S}$ tim u vezi, kada je riječ o općim zahtjevima za određenošću i preciznošću ovlašćujuće norme, osobito su vrijedna citiranja načelna stajališta Ustavnog suda izložena u Odluci i Rješenju br. U-I722/2009 od 6. travnja 2011. gdje se utvrđuje:

„Ustavni sud smatra nespornim da adresati pravne norme ne mogu stvarno i konkretno znati svoja prava i dužnosti, te predvidjeti posljedice svojeg ponašanja, ako pravna norma nije dovoljno određena i precizna. Zahtjev za određenošću i preciznošću pravne norme predstavlja ,jedan od temeljnih elemenata načela vladavine prava“ (...) i ključan je za postanak i održanje legitimiteta pravnog poretka. Time se osigurava da demokratski legitimirani zakonodavac samostalno zakonom razrađuje temeljna prava i slobode, da izvršna i upravna vlast raspolažu jasnim zakonskim i podzakonskim regulatornim mjerilima za svoje odluke, te da sudbena vlast i sudovi mogu provoditi kontrolu zakonitosti pravnog poretka (...) Kad se taj zahtjev ne poštuje, neodređeni i neprecizni zakoni ustavnopravno nedopušteno delegiraju dijelove ovlasti zakonodavca na subjektivno rješavanje od upravnih i sudbenih vlasti. (...) Pozitivni smisao zahtjeva za određenošću i preciznošću pravne norme, međutim, nije ispunjen ako građani, kao savjesne i razumne osobe, nagađaju o njezinu smislu i sadržaju, a njezini se primjenjivači često razilaze u njezinu tumačenju i primjeni u konkretnim slučajevima. Prijeporna tumačenja neke pravne norme, koja rezultiraju neujednačenom praksom upravnih i sudskih tijela, predstavljaju sigurnu naznaku pogrešaka i nedostataka u njezinoj određenosti." 62

Dakle, $s$ aspekta očuvanja vladavine prava, a osobito pripadajućih načela pravne sigurnosti i jednakosti pravnih subjekata pred zakonom, potrebno je osigurati ne samo zakonitost nego i relativnu predvidljivost normativnog djelovanja naredbodavca. ${ }^{63}$

60 Nije svejedno hoće li se neko područje urediti pravilnikom ili naredbom, jer o odabiru vrste akta ovise i svrha, način i intenzitet podzakonskog normiranja - od, primjerice, detaljnijeg propisivanja sadržaja i načina vođenja nekog registra, što može biti predmet pravilnika, no ne i naredbe, do privremene zabrane obavljanja određene djelatnosti radi trenutačne zaštite života ili zdravlja stanovništva, što može biti predmet isključivo naredbe.

61 Vidi tč. 5.2. obrazloženja Odluke i Rješenja br. U-I-722/2009 od 6. IV. 2011. (NN, br. 44/11). Opširnije infra.

${ }^{62}$ Ibid., tč. 5.1., vidi i tč. 16. obrazloženja Odluke br.: U-I-4469/2008 i dr. od 8. VII. 2013. (NN, br. 90/13). Ustavni sud se u recentnijim odlukama evidentno naslanja na praksu Europskog suda za ljudska prava, kao i njemačkog Saveznog ustavnog suda, vidi Omejec, „Hrvatska uprava“, cit., str. 11. Za prikaz ranijih odluka u kojima su formulirana danas mjerodavna stajališta o značaju (i sadržaju) načela vladavine prava vidi Lauc, op. cit., str. 61.

63 „Zahtjevi pravne sigurnosti i vladavine prava iz čl. 3. Ustava traže da pravna norma bude dostupna adresatima i za njih predvidljiva, to jest takva da oni mogu stvarno i konkretno znati svoja prava i obaveze kako bi se prema njima mogli ponašati.“, prema tč. 15. obrazloženja Rješenja br. U-I-4946/2012 od 12.6.2014. 
Drugim riječima, iako sam trenutak u kojem će (i hoće li uopće) te okolnosti nastati, nije moguće unaprijed odrediti, zakonodavac je dužan što preciznije i potpunije odrediti hipotezu naredbodavnog ovlaštenja ${ }^{64}$ odnosno što detaljnije opisati okolnosti u kojima se primjena interventne mjere s restriktivnim učinkom na određena temeljna prava i slobode smatra opravdanom i nužnom. Znakovito je da su ustavnosudska tijela u drugim kontinentalnim državama srednjoeuropske podskupine, poput SR Njemačke, Austrije i Mađarske, na vrlo usporedivoj osnovi, već zauzela načelna stajališta o ustavnopravnoj neprihvatljivosti općih zakonskih ovlaštenja. ${ }^{65}$ Imajući u vidu izneseno, smatramo da bi buduća naredbodavna ovlaštenja, kad god je to moguće, trebalo formulirati kategorički (,,u slučaju x ministar će zabraniti obavljanje djelatnosti y u trajanju od z"), tako da suspenzija određenog prava ili slobode ne predstavlja očitovanje volje naredbodavca nego zakonodavca, uz suspenzivni uvjet stupanja na snagu naredbe kada za to nastanu zakonom predviđeni uvjeti. Stupanjem na snagu takve naredbe samo bi se aktivirala privremena suspenzija određenog prava ili slobode koju je zakonodavac, pod precizno razrađenim uvjetima, već izrijekom legitimirao kao nužnu radi trenutačne zaštite pravnog poretka te života, sigurnosti, zdravlja stanovništva ili imovine veće vrijednosti u određenom upravnom području.

Ustavno načelo razmjernosti u ograničivanju prava i sloboda suštinski je neodvojivo od gore izloženih zahtjeva, jer ,nedostaci u preciznosti pravne norme mogu onemogućiti nadzor nad primjenom načela razmjernosti“" ${ }^{66}$ a u ovom kontekstu značajno je i stoga što se neposredno reflektira i na utvrđivanje i na korištenje naredbodavnih ovlaštenja. Drugim riječima, ono u jednakoj mjeri limitira normativnu autonomiju i zakonodavca i naredbodavca u ograničavanju sloboda i prava, čak i kad su određena ograničenja neophodna i utemeljena. Zakonodavac, dakako, ,ima

64 „Zakonodavac može na različite načine izbjeći neodređenost i nepreciznost pravne norme, uključujući i to da posebnim zakonskim definicijama odredi sadržaj pojedinim zakonskim pojmovima. No, pri tome je uvijek potrebno da činjenice-uvjeti u hipotezi zakonske norme sadrže elemente predvidljivosti ponašanja pravnih subjekata sukladne njezinom ustavnopravno prihvatljivom cilju“, prema tč. 5.2. obrazloženja Odluke i Rješenja br. U-I-722/2009.

65 O općim ovlaštenjima (ger. Globalermächtigung, Generalermächtigung) i njihovoj dopustivosti u njemačkom pravu šire u Karpen, Hans-Ulrich, Die Verweisung als Mittel der Gesetzgebungstechnik, De Gruyter, Berlin, 2013. (reizdanje), str. 80-89, vidi i Ossenbühl,, „Rechtsverordnung“, u: Isensee i Kirchof (ur.), Handbuch des Staatsrechts der Bundesrepublik Deutschland, cit., str. 273-274, Barić, op. cit., str. 142-146. Za ustavnosudsku praksu vidi osobito presude u predmetima BVerfGE 1, 14 (60) Südweststaat (1951) i BVerfGE 143, 38 (60) Rindfleischetikettierung (2016). O općem načelu prethodne zakonske determiniranosti sadržaja podzakonskog propisa i nedopustivosti „formalne zakonske delegacije“ (izv. formalgesetzlichen Delegation) u austrijskoj doktrini vidi Stelzer, Manfred, The Constitution of the Republic of Austria: A Contextual Analysis, Hart Publishing, Oxford, 2011., str. 87-90, za ustavnosudsku praksu vidi VfSlg. 4072/1961, VfSlg. 4300/1962, VfSlg. 16902/2003 i VfSlg. 17476/2005. U mađarskoj ustavnopravnoj doktrini uvriježilo se pak stajalište da svako opće ovlaštenje potencijalno narušava pravnu sigurnost te ga je gotovo nemoguće pomiriti s vladavinom prava, opširnije u Patyi, András i Téglási, András, „The constitutional basis of Hungarian public administration“, u: Patyi, András i Rixer, Adám (ur.), Hungarian Public Administration and Administrative Law, Schenk Verlag, Passau, 2014., str. 215 218, za ustavnosudsku praksu vidi A 6/1999. (IV.21.) $A B H$ i 15/2008. (II.28.) $A B H$.

66 Vidi tč. 5.2. Odluke i Rješenja br. U-I-722/2009, tč. 16. Odluke br. U-I-4469/2008. Štoviše, formalni kriteriji jasnoće, preciznosti i predvidljivosti zakonske norme dio su standardnih testova poštovanja načela razmjernosti, kako u našoj tako i u poredbenoj ustavnosudskoj praksi, opširnije u Krapac, op. cit., str. 246247, 250-151, vidi i Lauc, loc. cit. 
pravo ograničiti slobode ili prava zajamčena Ustavom, no to ograničenje mora biti učinjeno zbog ostvarenja legitimnog cilja propisanog Ustavom i razmjerno cilju koji se ograničenjem želi postići“ “. ${ }^{67}$ Privremena ograničenja, koja su za incidentne situacije predviđena dispozicijom ovlašćujućeg zakona, moraju prije svega biti: a) prikladna za ostvarenje legitimnog cilja (što je, dakako, ponovna uspostava redovitog stanja, a time i punog opsega privremeno ograničenih prava i sloboda) ${ }^{68}$ potom moraju biti: b) nužna, u smislu da za ostvarenje tog cilja nije moguće primijeniti drugu, manje restriktivnu normu, te u konačnici: c) uravnotežena, u smislu da šteta za temeljna prava i slobode $u$ koje se zadire takvim privremenim ograničenjem ne nadmašuje interes pravnog poretka ${ }^{69}$ Naredbodavac je pak dužan voditi računa o nužnom opsegu i intenzitetu mjera koje su mu na dispoziciji, te naravi potrebe za njihovom primjenom u svakom pojedinom slučaju, primjenjujući ih dosljedno i razmjerno legitimnom cilju, koji je utvrđen ovlašćujućim zakonom, kako iste ne bi djelovale restriktivnije nego što to zahtijeva incidentna situacija koja se privremeno uređuje naredbom. Imajući to na umu, ostaje za vidjeti u kojem će smjeru krenuti zakonodavna i upravna praksa.

\section{ZAKLJUČAK}

Kontrola objektivne ustavnosti naredbodavnih ovlaštenja je, kao što smo supra istaknuli, nedvojbeno u jurisdikciji Ustavnog suda. Međutim, nedorečenost novog uređenja naredbe kojim je taj akt izdvojen iz kruga provedbenih propisa, a da se pri tome nije jasno utvrdilo je li i naredba „propis“ ili što drugo, ostavlja otvorenim pitanje nadležnosti za kontrolu objektivne ustavnosti i zakonitosti samih naredbi. U ovom trenutku nesporno je jedino to da kontrolu zakonitosti naredbe nije moguće provesti u okviru objektivnog upravnog spora, čiji je predmet

${ }_{67}$ Rješenje br. U-I-4362/2007 od 10. II. 2009. (NN, br. 23/09), tč. 9.2. obrazloženja. Smatra se da legitimni cilj imaju ograničenja koja proizlaze ,iz potreba zaštite interesa i sigurnosti Republike Hrvatske, prirode, ljudskog okoliša, zdravlja ljudi, slobode i prava drugih ljudi, pravnog poretka i javnog morala, sukladno odredbama čl. 16. st. 1. i čl. 50. st. 2. Ustava“, prema Rješenju br. U-I-266/2003 od 14. VI. 2006. (NN, br. 78/06). O tome postoji li nužna veza između ustavnih prava i primjene načela razmjernosti (s obranom teze o nužnosti) opširnije u Alexy, Robert, „Constitutional Rights and Proportionality“, Revus, 22(1), 2014., str. 51-65.

68 Vidi Odluku i Rješenje br. U-I-673/1996 od 21. IV. 1999. (NN, br. 39/99), čiji se osobit značaj ogleda u tome što je načelo razmjernosti tada prvi put utvrđeno kao „opće ustavno načelo, imanentno svim Ustavnim odredbama o slobodama i pravima čovjeka i građanina“. Za komentar vidi Crnić, Jadranko, „Ustavni sud Republike Hrvatske: iskustva i perspektive“, Politička misao, 38(4), 2001., str. 136-137, vidi i Smerdel, op. cit., str. 41, 55.

69 Već u Odluci br.: U-I-1156/1999 od 26. I. 2000. (NN, br. 14/00) Ustavni je sud zauzeo načelno stajalište da će ,ograničenje poduzetničkih sloboda i vlasničkih prava, premda je poduzeto s legitimnim ciljem, povrijediti gospodarska prava propisana Ustavom Republike Hrvatske u svakom onom slučaju kada je očito da ne postoji razuman odnos razmjernosti između načina ili opsega ograničenja poduzetničkih sloboda i vlasničkih prava pojedinaca i ciljeva koji se žele postići u javnom interesu. Razmjernost, naime, može postojati samo u slučaju ako poduzete mjere nisu restriktivnije no što je potrebno da bi se osigurao pravovaljan (legitiman) cilj“. Vidi i Odluku i Rješenje br. U-I-131/1998 od 3. II. 2000. (NN, br. 20/00). Za širi pregled domaće i poredbene (poglavito njemačke) ustavnosudske prakse vidi Krapac, op. cit., str. 246-251, vidi i Smerdel, op. cit., str. 54-55, 303-306. 
isključivo kontrola objektivne zakonitosti općeg akta jedinice lokalne i područne (regionalne) samouprave, pravne osobe s javnim ovlastima i pravne osobe koja obavlja javnu službu. Ako bi se i Ustavni sud povodom nekog (vjerujemo vrlo izvjesnog) budućeg zahtjeva/prijedloga za ocjenu ustavnosti ili zakonitosti naredbe oglasio nenadležnim, uz obrazloženje da je naredba u ZSDU/19 izdvojena iz kruga provedbenih propisa, te da stoga nije ,drugi propis“, to bi dovelo do ustavnopravno neprihvatljive situacije da niti jedno (nepolitičko) tijelo nije ovlašteno za ukidanje (ili poništavanje) nezakonite, odnosno neustavne naredbe.

Prihvati li nadležnost, pred Ustavnim sudom još ostaje izbor između a) redefiniranja stajališta utvrđenog Odlukom br. U-I-3845/2006, kako bi se naredbu podvelo pod definiciju „,drugog propisa“, i b) posizanja za iznimkom koju je utvrdio Rješenjem br. U-II-5157/2005, odnosno „osobitim ustavnopravnim razlozima zaštite ljudskih prava i temeljnih sloboda zajamčenih Ustavom i drugih najviših vrednota ustavnog poretka Republike Hrvatske utvrđenih u članku 3. Ustava“, u kojem slučaju se provodi kontrola ustavnosti i zakonitosti i općeg akta tijela državne vlasti (donositelji naredbe su nedvojbeno tijela državne vlasti) koji ima samo jedno materijalno obilježje „drugog propisa“ (apstraktnost ili generalnost), uslijed čega bi sporna naredba u okviru ustavnosudskog postupka također bila tretirana kao „drugi propis“. Stajališta smo da u potonjem slučaju postoje sve pretpostavke za odlučivanje o biti stvari, s obzirom na donositelje te supra izloženu pravnu prirodu, svrhu i normativni sadržaj naredbe. Pri tome bi, mišljenja smo, pored općeg načela zakonitosti (koje ZSDU/19 postavlja pred sve nositelje normativnih ovlaštenja) i načela pravne sigurnosti, trebalo osobito uzeti u obzir i načelo razmjernosti, pomoću kojeg je moguće ocijeniti i to je li naredbodavac mjere koje su mu bile na dispoziciji primijenio dosljedno i razmjerno legitimnom cilju koji je utvrđen ovlašćujućim zakonom, odnosno jesu li te mjere djelovale restriktivnije nego što je to zahtijevala incidentna situacija koja se privremeno normirala naredbom.

\section{LITERATURA}

\section{Monografska djela, znanstveni i stručni članci}

1. Alexy, Robert, „Constitutional Rights and Proportionality“, Revus, 22(1), 2014., str. 51-65.

2. Babac, Branko, „Ogled o obnovi naučavanja o naredbi u hrvatskim upravnim znanostima“, Pravni vjesnik, 15(1-2), 1999., str. 65-122.

3. Bačić, Arsen, „Vladavina prava i institucije kontrole ustavnosti zakona“, u: Crnić, Jadranko i Filipović, Nikola (ur.), Ustavni sud u zaštiti ljudskih prava, interpretativna uloga Ustavnog suda, Organizator, Zagreb, 2000., str. 25-57.

4. Banić, Slavica, „Režim općih akata nakon donošenja zakona o upravnim sporovima (2010)“, Zbornik radova Pravnog fakulteta u Splitu, 50(3), 2013., str. 573-588.

5. Barić, Sanja, Zakonodavna delegacija i parlamentarizam u suvremenim europskim državama, Organizator, Zagreb, 2009. 
6. Bartling, Björn i Fischbacher, Urs, „Shifting the Blame: On Delegation and Responsibility“, The Review of Economic Studies, 79(1), 2012., str. 67-87.

7. Borković, Ivo, Upravno pravo, Narodne novine, Zagreb, 2002.

8. Crnić, Jadranko, „Ustavni sud Republike Hrvatske: iskustva i perspektive“, Politička misao, 38(4), 2001., str. 126-145.

9. Čepulo, Dalibor, „Vladavina prava i pravna država - europska i hrvatska pravna tradicija i suvremeni izazovi“, Zbornik Pravnog fakulteta u Zagrebu, 61(6), 2001., str. 1337-1361.

10. Fiorina, Morris P., „Legislative Choice of Regulatory Forms: Legal Process or Administrative Process?“, Public Choice, 39(1), 1982, str. 33-66.

11. Hamburger, Philip, Is Administrative Law Unlawful?, University of Chicago Press, Chicago/London, 2014.

12. Ivančević, Velimir, Institucije upravnog prava - knjiga I, Pravni fakultet Sveučilišta u Zagrebu, Zagreb, 1983.

13. Jellinek, Georg, Gezetz und Verordnung, Staatsrechtliche Untersuchungen auf rechtsgeschichtlicher und rechtsvergleichender Grundlage, Mohr, Freiburg, 1887.

14. Karpen, Hans-Ulrich, Die Verweisung als Mittel der Gesetzgebungstechnik, De Gruyter, Berlin, 2013.

15. Krapac, Davor, Postupak pred Ustavnim sudom Republike Hrvatske, ustrojstvo $i$ proceduralni elementi ustavnog nadzora, Narodne novine, Zagreb, 2014.

16. Krbek, Ivo, Upravno pravo, I. knjiga, Uvodna i osnovna pitanja, Zagreb, Tisak i naklada Jugoslovenske štampe, Zagreb, 1929.

17. Krbek, Ivo, Sudska kontrola naredbe, Jugoslavenska akademija znanosti i umjetnosti, Tisak zaklade tiskare Narodnih novina, 1939.

18. Laband, Paul, Das Staatsrecht des Deutschen Reiches, Mohr, Freiburg, 1895.

19. Lauc, Zvonimir, „Načelo vladavine prava u teoriji i praksi“, Pravni vjesnik, 32(3-4), 2016., str. 45-67.

20. Omejec, Jasna, „Izvanredna stanja u pravnoj teoriji i ustavima pojedinih zemalja“, Pravni vjesnik, 12(1-4) 1996., str. 172-196.

21. Omejec, Jasna, „O potrebnim promjenama u strukturi hrvatskog ustavnog sudovanja (prilog reformi ustavnog sudovanja)"u: Barbić, Jakša (ur.), Zbornik radova s okruglog stola Hrvatske akademije znanosti i umjetnosti: Hrvatsko ustavno sudovanje de lege lata $i$ de lege ferenda, Hrvatska akademija znanosti i umjetnosti, Zagreb 2009., str. 23-167.

22. Omejec, Jasna, „Hrvatska uprava - od socijalističkog do europskog koncepta zakonitosti“, str. 1-37, rad objavljen u knjizi: Gjidara, Marc, Aviani, Damir i Britvić Vetma, Bosiljka (ur.), Hrvatsko-francuski upravnopravni dani. Hrestomatija I - opći dio: Javna uprava, Pravni fakultet Sveučilišta u Splitu, Sveučilište Panthéon Assas Paris II, Državni savjet Francuske Republike, Split/Pariz, 2016., str. 99-141.

23. Omejec, Jasna i Banić, Slavica, „Diferencijacija propisa i općih akata u budućoj praksi Ustavnog suda i Upravnog suda u povodu Zakona o upravnim sporovima“, Zbornik radova Pravnog fakulteta u Splitu, 49(2), 2012., str. 309-324. 
24. Ossenbühl, Fritz, „Vorrang und Vorbehalt des Gesetzes“, u: Isensee, Josef i Kirchof, Paul (ur.), Handbuch des Staatsrechts der Bundesrepublik Deutschland, Band V, Rechtsquellen, Organisation, Finanzen, C.F. Müller, Heidelberg, 2007., str. 183-222.

25. Ossenbühl, Fritz, „Rechtsverordnung“, u: Isensee, Josef i Kirchof, Paul (ur.), Handbuch des Staatsrechts der Bundesrepublik Deutschland, Band V, Rechtsquellen, Organisation, Finanzen, C.F. Müller, Heidelberg, 2007., str. 261-304.

26. Patyi, András i Téglási, András, „The constitutional basis of Hungarian public administration“, u: Patyi, András i Rixer, Ádám (ur.), Hungarian Public Administration and Administrative Law, Schenk Verlag, Passau, 2014., str. 203-218.

27. Perić, Berislav, Struktura prava, Informator, Zagreb, 1994.

28. Pünder, Hermann, „Verwaltungsverfahren“, u Erichsen, Hans-Uwe i Ehlers, Dirk (ur.), Allgemeines Verwaltungsrecht, De Gruyter, Berlin, 2011., str. 365-514.

29. Salzberger, Eli M. i Voigt, Stefan, „On Constitutional Processes and the Delegation of Power, with special emphasis on Israel and Central and Eastern Europe“, Theoretical Inquiries in Law, 3(1), 2002., str. 207-263.

30. Schoenbrod, David, Power Without Responsibility - How Congress Abuses the People Through Delegation, Yale University Press, London, 1993.

31. Smerdel, Branko, Ustavno uređenje europske Hrvatske, Narodne novine, Zagreb, 2013.

32. Stelzer, Manfred, The Constitution of the Republic of Austria: A Contextual Analysis, Hart Publishing, Oxford, 2011.

33. Vidaković Mukić, Marta, Opći pravni rječnik, Narodne novine, Zagreb, 2006.

34. Weaver, Kent R., „The Politics of Blame Avoidance“, Journal of Public Policy, 6(4), 1986., str. 371-398.

\section{PRAVNI IZVORI}

\section{Propisi}

1. Ustav Republike Hrvatske (NN, br. 85/10 - pročišćeni tekst, 5/14)

2. Ustavni zakon o Ustavnom sudu Republike Hrvatske (NN, br. 99/99, 29/02)

3. Zakon o sustavu državne uprave (NN, br. 66/19)

4. Zakon o sustavu državne uprave (NN, br. 150/11, 12/13, 93/16, 104/16)

5. Zakon o sustavu državne uprave (NN, br. 75/93, 92/96, 48/99, 15/00, 59/01, 199/03, 79/07)*70

6. Zakon o ovlasti Vlade Republike Hrvatske da uredbama uređuje pojedina pitanja iz djelokruga Hrvatskog sabora (NN, br. 118/19)

7. Zakon o upravnim sporovima (NN, br. 20/10, 143/12, 152/14, 94/16, 29/17)

8. Zakon o otpisu dugova fizičkim osobama (NN, br. 62/18)

9. Zakon o zaštiti prirode (NN, br. 80/13, 15/18, 14/19)

nevažeći propis 
10. Zakon o suzbijanju zlouporabe droga (NN, br. 107/01, 87/02, 163/03, 141/04, 40/07, $149 / 09,84 / 11,80 / 13,39 / 19)$

11. Zakon o zaštiti životinja (NN, br. 102/17, 32/19)

12. Zakon o hrani (NN 81/13, 14/14, 30/15, 115/18)

13. Zakon o prehrambenim aditivima, aromama i prehrambenim enzimima (NN, br. $39 / 13,114 / 18)$

14. Zakon o provedbi Uredbe (EZ) br. 648/2004 Europskoga parlamenta i Vijeća od 31. ožujka 2004. godine o deterdžentima (NN, br. 34/12, 25/13 i 114/18)

15. Zakon o informiranju potrošača o hrani (NN, br. 56/13, 14/14, 56/16, 32/19)

16. Zakon o službenim kontrolama koje se provode sukladno propisima o hrani, hrani za životinje, o zdravlju i dobrobiti životinja (NN, br. 81/13, 14/14, 56/15, 32/19)

17. Zakon o provedbi Uredbe (EZ) br. 1107/2009 o stavljanju na tržište sredstava za zaštitu bilja (NN, br. 80/13, 32/19)

18. Naredba o poduzimanju mjera obveznog uklanjanja ambrozije (NN, br. 72/07)

19. Naredba o privremenim mjerama u odnosu na sadržaj aflatoksina M1 u mliječnim proizvodima (NN, br. 39/13)

20. Naredba o stavljanju na tržište upaljača sigurnih za djecu i zabrani stavljanja na tržište upaljača »noviteta« (NN, br. 19/11, 54/11, 40/12, 58/13, 57/14, 26/15, 71/16)

21. Naredba o zabrani uporabe didušikovog monoksida (NN, br. 69/19)

22. Naredba o mjerama za sprečavanje pojave i ranog otkrivanja unosa virusa afričke svinjske kuge na području Republike Hrvatske (NN, br. 111/18)

23. Naredba o mjerama zaštite zdravlja životinja od zaraznih i nametničkih bolesti i njihovom financiranju u 2019. godini (NN, br. 5/19)

24. Jedinstvena metodološko-nomotehničkih pravila za izradu akata koje donosi Hrvatski sabor (NN, br. 74/15)

\section{USTAVNOSUDSKA PRAKSA}

\section{Ustavni sud Republike Hrvatske}

1. Odluka i Rješenje br. U-I-673/1996 od 21. IV. 1999. (NN, br. 39/99)

2. Odluka br.: U-I-1156/1999 od 26. I. 2000. (NN, br. 14/00)

3. Odluka i Rješenje br. U-I-131/1998 od 3. II. 2000. (NN, br. 20/00)

4. Rješenje br. U-I-709/1995 od 1. III. 2000.

5. Rješenje br. U-I-38/2000 od 15. XI. 2000.

6. Rješenje br. U-II-364/2001 od 12. IV. 2001.

7. Rješenje br. U-I-266/2003 od 14. VI. 2006. (NN, br. 78/06)

8. Rješenje br. U-I-4362/2007 od 10. II. 2009. (NN, br. 23/09)

9. Odluka i Rješenje br. U-I-722/2009 od 6. IV. 2011. (NN, br. 44/11)

10. Rješenje br. U-II-5157/2005 od 5. III. 2012. (NN, br. 41/12)

11. Odluka br. U-I-3845/2006 od 23. I. 2013. (NN, br. 12/13)

12. Odluka br. U-I-4469/2008 i dr. od 8. VII. 2013. (NN, br. 90/13) 
13. Odluka br.: U-II-5748/2013 od 20. XII. 2013. (NN, br. 159/13)

14. Rješenje br. U-I-4946/2012 od 12. VI. 2014.

15. Odluka br. U-I-2813/2014 od 3. VI. 2016.

16. Rješenje br. U-II-3104/2014 od 8. XI. 2016.

17. Rješenje br. U-I-4455/2015 od 4. IV. 2017.

18. Odluka br. U-II-13/2016 od 11. VII. 2017. (NN, br. 90/17)

19. Odluka i Rješenje br. U-II 2064/2010 od 23. V. 2018. (NN, br. 51/18)

\section{Savezni ustavni sud, Savezna Republike Njemačka}

1. BVerfGE 1, 14 (60) Südweststaat (1951.)

2. BVerfGE 143, 38 (60) Rindfleischetikettierung (2016.)

\section{Ustavni sud Republike Austrije}

1. VfSlg. 4072/1961

2. VfSlg. 4300/1962

3. VfSlg. $16902 / 2003$

4. VfSlg. 17476/2005

\section{Ustavni sud Mađarske}

1. A 6/1999. (IV.21.) $A B H$

2. $15 / 2008$. (II.28.) $A B H$ 


\section{CONSTITUTIONALITY AND LEGALITY CONTROL OF ORDERS}

Legislative authorisation to issue orders essentially enables timely regulation of various emergency situations, in which such an order is usually demanding an action or omission that is otherwise not mandatory, or prohibiting an action that is otherwise legally permitted. However, our legislative practice thus far has shown that such legislative authorisation often contain vague or general formulations, without clearly defined boundaries of the authority on the basis of which some additional restrictions or obligations are regularly imposed on business entities for the duration of an intervention measures. This paper primarily examines the vagueness of the new systematic regulation of orders, which leaves open the question of the competence for the review of the constitutionality and legality of this generally binding subordinate legislation. Specifically, an order cannot be the subject of an objective administrative dispute at the moment, and the jurisdiction of the Constitutional Court is also questionable, since the State Administration System Act no longer explicitly defines an order as an implementing regulation. Consequently, the main part of the paper analyses the basic substantive features and legal nature of the order, examines the issue of the necessary degree of specificity and precision of the authorising norm as well as the role of the proportionality principle in the necessary limitation of the regulatory autonomy of the legislator and the issuers of orders, and, in conclusion, seeks to answer the question of whether the order should (and can) be subject to constitutionality and legality review by the Constitutional Court.

Key words: Orders, Limitation of basic Rights and Freedoms, Rule of Law, Legal certainty, Proportionality 